Journal of

Molecular Microbiology

and Biotechnology

\title{
Advances in Recovery of Novel Biocatalysts from Metagenomes
}

\author{
Helen L. Steele ${ }^{a}$ Karl-Erich Jaeger ${ }^{b}$ Rolf Daniel ${ }^{c}$ Wolfgang R. Streit ${ }^{a}$ \\ a Biozentrum Klein Flottbek, Abteilung für Mikrobiologie \& Biotechnologie, Universität Hamburg, Hamburg; \\ ${ }^{b}$ Institut für Molekulare Enzymtechnologie, Heinrich-Heine-Universität Düsseldorf, Forschungszentrum Jülich, \\ Jülich; ${ }^{C}$ Abteilung für Genomische und Angewandte Mikrobiologie, Institut für Mikrobiologie und Genetik der \\ Georg-August-Universität, Göttingen, Germany
}

\section{Key Words}

Metagenomics • Biocatalyst • Functional screening • Heterologous host

\begin{abstract}
Metagenomics has accelerated the process of discovery of novel biocatalysts by enabling scientists to tap directly into the entire diversity of enzymes held within natural microbial populations. Their characterization has revealed a great deal of valuable information about enzymatic activity in terms of factors which influence their stability and activity under a wide range of conditions. Many of the biocatalysts have particular properties making them suitable for biotechnological applications. A diverse array of strategies has been developed to optimize each step of the process of generating and screening metagenomic libraries for novel biocatalysts. This review covers the diversity of metagenome-derived enzymes characterized to date, and the strategies currently being developed to optimize discovery of novel metagenomic biocatalysts.

Copyright $\odot 2008$ S. Karger AG, Basel
\end{abstract}

\section{Introduction}

Prokaryotes are able to grow in a vast range of environments, from alkaline lakes to hydrothermal vents, indicating that they carry enzymes which are stable and active under these extreme conditions [Grant et al., 2004; Purcarea et al., 2001; Rothschild and Mancinelli, 2001]. These biocatalysts are of interest because they have potential applications in industrial processes, but the majority of microorganisms from such environments, although active, are usually recalcitrant to cultivation [Amann et al., 1995; Ouverney and Fuhrman, 2000]. The fact that traditionally biocatalysts could only be obtained from bacterial isolates was one of the main limitations to the widespread application of biocatalysts in industry [Leresche and Meyer, 2006].

The field of metagenomics developed from advances made in DNA extraction and cloning from environmental samples [Schmidt et al., 1991; Tsai and Olson, 1992]. Around the same time, the application of molecular techniques revealed that prokaryotic diversity had been greatly underestimated and it became apparent that there remained a great deal of biocatalytic potential locked within the unculturable majority of prokaryotes [Amann et al., 1995; Handelsman et al., 1998; Hugenholtz et al., 1998; Streit and Schmitz, 2004]. Current computed estimates of

\section{KARGER \\ Fax +4161306 1234 \\ E-Mail karger@karger.ch}

www.karger.com (c) 2008 S. Karger AG, Basel

$1464-1801 / 09 / 0162-0025 \$ 26.00 / 0$

Accessible online at:

www.karger.com $/ \mathrm{mmb}$
Prof. Dr. W.R. Streit

Universität Hamburg, Biozentrum Klein Flottbek

Ohnhorststrasse 18, DE-22609 Hamburg (Germany)

Tel: +49 4042816463 , Fax +494042816459

E-Mail wolfgang.streit@uni-hamburg.de 
Table 1. Amylolytic clones from metagenomic DNA

\begin{tabular}{|c|c|c|c|c|c|c|c|}
\hline \multicolumn{5}{|c|}{ Library details } & \multicolumn{2}{|c|}{ Amylolytic clones } & \multirow[t]{2}{*}{ Reference } \\
\hline source & vector & $\begin{array}{l}\text { clone } \\
\text { number }\end{array}$ & $\begin{array}{l}\text { average } \\
\text { insert size }\end{array}$ & total size & $\begin{array}{l}\text { total } \\
\text { number }\end{array}$ & level of characterization & \\
\hline Soil & BAC & 3,648 & $27 \mathrm{~kb}$ & $100 \mathrm{Mb}$ & 8 & restriction analysis & Rondon et al., 2000 \\
\hline Various & plasmid & 50,000 & not specified & not specified & 3 & protein purification, $\mathrm{pH},{ }^{\circ} \mathrm{C}$ & Richardson et al., 2002 \\
\hline Soil & cosmid & 1,532 & $32.5 \mathrm{~kb}$ & $49.8 \mathrm{Mb}$ & 1 & sequencing & Voget et al., 2003 \\
\hline Soil & plasmid & 30,000 & $3.5 \mathrm{~kb}$ & $105 \mathrm{Mb}$ & 1 & protein purification, $\mathrm{pH},{ }^{\circ} \mathrm{C}$ & Yun et al., 2004 \\
\hline Cow gut & phage $\lambda$ vector & 14,000 screened & $5.5 \mathrm{~kb}$ & $77 \mathrm{Mb}$ screened & 1 & activity of crude extract & Ferrer et al., 2005b, 2007 \\
\hline
\end{tabular}

soil diversity are in the range of a million species per $1 \mathrm{~g}$ of soil [Curtis and Sloan, 2005; Gans et al., 2005]. Metagenomics now enables access to the biocatalytic potential of unculturable microorganisms [Lorenz and Eck, 2005; Steele and Streit, 2005].

\section{Novel Enzymes from Metagenomes}

Metagenomic libraries have been screened for a wide range of biocatalysts [Streit et al., 2004]. Their level of characterization depends strongly on the final application of the biocatalyst. For example, when analyzing metagenomic genes involved in biotin synthesis, the level of enzyme activity is important, and when analyzing metagenomic esterases or cellulases, their stability under a wide range of conditions is as important as their level of activity and substrate range. Many metagenomic biocatalysts, as well as displaying novel substrate/product ranges, are also often highly stable under extreme conditions and therefore have potential applications in industries including the food industry and the production of fine chemicals.

\section{Polysaccharide Degrading/Modifying Enzymes}

Agar is used as a solidifying agent in molecular biology research and as an additive in the food industry. Agarases are the enzymes which can liquify agar and they can be divided into $\alpha$ and $\beta$ agarases, depending on whether they cleave the $\alpha-\mathrm{L}-(1,3)$ or the $\beta$-D- $(1,4)$ linkages of the polymer. The majority of research into agarases concentrates on those found in cultured bacteria belonging to a limited number of phyla and classes, and mainly isolated from marine environments [Michel et al., 2006]. However, the screening of a soil metagenomic library containing 1,532 clones revealed a total of 4 agarolytic clones containing 12 agarase genes [Voget et al.,
2003]. This highlights the potential of using metagenomics to investigate environments for novel biocatalysts which are normally detected in isolates from unrelated environments.

Amylases have many industrial applications, especially in the detergent and food industries, and so far this has been limited to those obtained from cultured microorganisms. As the industrial processes require amylases which are particularly stable over a wide range of $\mathrm{pH}$ and temperature conditions, amylases have been predominantly isolated from extremophiles [Pakchung et al., 2006; Rothschild and Mancinelli, 2001]. To date there have been five articles reporting the detection and characterization of novel amylolytic enzymes from metagenomic DNA libraries [Ferrer et al., 2005b; Richardson et al., 2002; Rondon et al., 2000; Voget et al., 2003, Yun et al., 2004] (table 1). Of the 14 amylolytic clones, only 4 have been purified and characterized [Richardson et al., 2002; Yun et al., 2004]. One of the characterized amylases, from a soil metagenome, displayed interesting characteristics in that it is stable and active under alkaline conditions, with a $\mathrm{pH}$ optimum at $\mathrm{pH}$ 9.0, a characteristic required of amylases in detergents [Rothschild and Mancinelli, 2001; Yun et al., 2004]. The other three amylases were active under acidic $\mathrm{pH}$ and high temperature conditions, and these were then subjected to gene reassembly in order to obtain one enzyme displaying optimal properties [Richardson et al., 2002]. Gene reassembly and directed evolution are two methods used to modify natural enzymes at the genetic level in order to optimize them [Chatterjee and Yuan, 2006; Jaeger et al., 2001].

Among many biotechnological applications, cellulases are used in the generation of bioethanol as well as being applied for the polishing and finishing of textiles [Lynd et al., 2002; Ragauskas et al., 2006]. Functional screening of a soil metagenomic library for cellulases revealed a to- 
tal of 8 cellulolytic clones, one of which was purified and characterized [Voget et al., 2006]. Despite the fact that this library had been generated from a soil sample collected from a non-extreme environment, the cellulase displayed a high level of stability over a broad $\mathrm{pH}$ range, up to $\mathrm{pH} 9$, it was stable at $40^{\circ} \mathrm{C}$ for up to $11 \mathrm{~h}$ and it was highly halotolerant being active and stable in $3 \mathrm{M} \mathrm{NaCl}$ [Voget et al., 2006]. The use of cellulases in detergents requires that they are stable under alkaline conditions [Rothschild and Mancinelli, 2001]. In some cases, thermotolerant cellulases are stabilized at high temperature by high salt concentrations [Bronnenmeier et al., 1995; Liebl et al., 1996]. Metagenomic screening of extreme environments, soda lakes in Africa and Egypt, detected more than a dozen cellulases, some of which displayed habitat-related halotolerant characteristics [Grant et al., 2004; Rees et al., 2003].

One of the earliest articles presenting metagenomederived biocatalysts reported the detection of cellulases from a thermophilic, anaerobic digester fueled by lignocellulose [Healy et al., 1995]. In this study, 12 cellulolytic clones were detected and sequenced. Four of them were characterized further in terms of their temperature and $\mathrm{pH}$ optima and shown to be thermotolerant [Healy et al., 1995].

While most metagenomic surveys for novel cellulases concentrate on extreme environments, there is sufficient evidence that non-extreme, and therefore highly genetically diverse, environments also contain a range of cellulases which are highly stable and suitable for industrial applications [Voget et al., 2006].

Chitinases are responsible for the breakdown and recycling of chitin. With several gigatons of chitin being produced annually, it is the second most abundant polymer in nature after cellulose [Howard et al., 2003]. Chitinases have several biotechnological applications including increasing plant resistance to fungal disease [Carstens et al., 2003]. To date, there has been only one metagenomic study targeting chitinases from a marine environment [Cottrell et al., 1999]. They investigated two different marine environments and used two different methods to screen for chitinases which resulted in the detection of many chitinase-producing clones. While the metagenomic approach provides access to chitinases from cultured and uncultured microorganisms, much can still be learnt from investigating cultured microorganisms for novel chitinases [Hoster et al., 2005].

Xylanases are hydrolytic enzymes which break down the plant cell wall polysaccharide xylan, and they have biotechnological applications in the food and agriculture industries as well as in paper and textiles industries [Collins et al., 2005]. Complete hydrolysis of xylan to xylose also involves the activity of xylosidases. There have been three studies detecting xylanases/xylosidases in the metagenomes of diverse environments: an insect gut, a thermophilic, anaerobic digester and waste lagoon of a dairy farm [Brennan et al., 2004; Healy et al., 1995; Lee et al., 2006a]. Screening of the lagoon resulted in the detection and characterization of one xylanase which displayed habitat-related properties in that it was most active at lower temperatures [Lee et al., 2006a]. The 4 xylosidases detected in the digester were not investigated further, but the cellulases found in the same study were thermophilic [Healy et al., 1995]. The metagenomic survey of the insect gut discovered 4 xylanases which were phylogenetically distant from all other known xylanases, suggesting that they had evolved independently [Brennan et al., 2004]. These xylanases are novel and produce unique hydrolysis products. They also displayed habitat-related properties, being most active at acidic $\mathrm{pH}$ and with a temperature optimum at $50^{\circ} \mathrm{C}$ [Brennan et al., 2004]. The microorganisms present in insect gut are difficult to cultivate and it was only through the application of metagenomics that the biocatalysts involved in hydrolysis processes in the insect gut could be obtained and characterized.

\section{Lipolytic Biocatalysts}

The development of metagenomics has greatly accelerated the discovery of novel biocatalysts, many displaying unusual properties. For example, since the first reported screen for detection of lipolytic activity in metagenomic clone libraries in 2000, there have been 13 publications reporting a total of 76 esterase- or lipasepositive clones (table 2). The level of characterization of these novel lipolytic genes ranges from DNA restriction and sequencing analysis to determine clone diversity [Rondon et al., 2000; Voget et al., 2003] to detailed biochemical analysis of the purified enzyme [Elend et al., 2006; Ferrer et al., 2005a; Rhee et al., 2005]. Of the 76 lipolytic-positive clones listed in table 2 , only 11 have been overexpressed, purified and subjected to detailed biochemical characterization. It is because of the high number of novel enzymes which can be detected by the screening of a single metagenomic library, and the amount of time and effort required to fully characterize one enzyme which causes this bottleneck.

Esterases and lipases have a growing number of applications in biotechnology, in particular in fine chemicals industries because of their enantioselectivity and stere- 
Table 2. Lipolytic clones from metagenomic DNA

\begin{tabular}{|c|c|c|c|c|c|c|c|c|}
\hline \multirow[t]{3}{*}{ Soil } & plasmid & 73,000 & 6.5 & $474.5 \mathrm{Mb}$ & 1 & $1 / 474.5 \mathrm{Mb}$ & $1 / 730,000$ & \multirow[t]{3}{*}{ Henne et al., 2000} \\
\hline & plasmid & 180,000 & 6.5 & $1,170 \mathrm{Mb}$ & 1 & $1 / 1170 \mathrm{Mb}$ & $1 / 180,000$ & \\
\hline & plasmid & 98,000 & 6.5 & $637 \mathrm{Mb}$ & 2 & $1 / 318.5 \mathrm{Mb}$ & $1 / 49,000$ & \\
\hline Soil & cosmid & 1,532 & 32.5 & $49.8 \mathrm{Mb}$ & 1 & $1 / 49.8 \mathrm{Mb}$ & $1 / 1,532$ & Voget et al., 2003 \\
\hline \multirow[t]{2}{*}{ Kenyan soda lakes } & phagemid & 60,000 & 6 & $360 \mathrm{Mb}$ & $2^{\mathrm{b}}$ & $1 / 180 \mathrm{Mb}$ & $1 / 30,000$ & \multirow[t]{2}{*}{ Rees et al., 2003} \\
\hline & phagemid & 100,000 & 6 & $600 \mathrm{Mb}$ & 1 & $1 / 600 \mathrm{Mb}$ & $1 / 100,000$ & \\
\hline Topsoil & fosmid & 33,700 & 35 & $1,179.5 \mathrm{Mb}$ & 8 & $1 / 147 \mathrm{Mb}$ & $1 / 4213$ & Lee et al., 2004 \\
\hline Hot spring & fosmid & 10,214 & 40 & $408.6 \mathrm{Mb}$ & 10 & $1 / 40.9 \mathrm{Mb}$ & $1 / 1,021$ & Kim et al., 2005 \\
\hline Deep-sea hypersaline basin & phagemid & $\begin{array}{l}4 \times 10^{8} \text { total } \\
\% \text { screened } \\
\text { unspecified }\end{array}$ & 5 & $\begin{array}{l}\text { 2,000 Gb } \\
\% \text { screened } \\
\text { unspecified }\end{array}$ & $5^{\mathrm{b}}$ & - & - & Ferrer et al., 2005a \\
\hline Cow gut & phagemid & $\begin{array}{c}14,000 \\
\text { screened }\end{array}$ & 5.5 & $\begin{array}{c}77 \mathrm{Mb} \\
\text { screened }\end{array}$ & 11 & $1 / 7 \mathrm{Mb}$ & $1 / 1,273$ & Ferrer et al., 2005b \\
\hline Mud flats, beach \& forest & fosmid & 6,000 & 35 & $210 \mathrm{Mb}$ & 5 & $1 / 42 \mathrm{Mb}$ & $1 / 1,200$ & Kim et al., 2006 \\
\hline Drinking water & cosmid & 1,600 & 35 & $56 \mathrm{Mb}$ & 6 & $1 / 9.3 \mathrm{Mb}$ & $1 / 267$ & Elend et al., 2006, 2007 \\
\hline Soil & cosmid & 2,500 & 35 & $87.5 \mathrm{Mb}$ & $2^{\mathrm{b}}$ & $1 / 87.5 \mathrm{Mb}$ & $1 / 2,500$ & \\
\hline
\end{tabular}

oselective properties [Jaeger and Eggert, 2002]. Among the characterized metagenomic esterases found so far are two of the largest esterases known: a $325-\mathrm{kDa}$ esterase from a deep-sea hypersaline anoxic basin, and a $336-\mathrm{kDa}$ octameric esterase from a drinking water biofilm [Elend et al., 2006; Ferrer et al., 2005a]. The esterases from the deep-sea hypersaline basin display habitat-related properties in that they were most active at alkaline $\mathrm{pH}$ and displayed higher activities under high pressure conditions [Ferrer et al., 2005a]. The esterases from soil and a drinking water biofilm displayed unusual properties which could not be related to their environment [Elend et al., 2006]. They were highly stable at alkaline $\mathrm{pH}$ and dis- played unique substrate spectra with EstA3 being able to hydrolyze substrates such as 7-[3-octylcarboxy-(3-hydroxy-3-methyl-butyloxy)]-coumarin, a normally unreactive secondary ester [Elend et al., 2006]. Within this framework, ibu- and ketoprofen-specific enzymes have recently been reported. One of these enzymes specifically acts on R-ibuprofen esters [Elend et al., 2007] and the second enzyme is highly specify for the S-enatiomer of ketoprofen [Yoon et al., 2007]. Both enzymes have been characterized to a very detailed level.

Despite the fact that many interesting novel lipolytic biocatalysts are discovered using metagenomics, the majority of the biocatalysts remain uncharacterized. This 
bottleneck prevents metagenomic research delivering the full potential of biocatalysts to the biotechnology industries.

\section{Vitamin Biosynthesis}

Metagenomics has been applied to the search for novel genes encoding the synthesis of vitamins such as biotin and vitamin C [Entcheva et al., 2001; Eschenfeldt et al., 2001]. Seven cosmids were detected in metagenomic libraries obtained after avidin enrichment of environmental samples [Entcheva et al., 2001]. The highest levels of biotin production in this study were detected in a cosmid obtained from forest soil [Entcheva et al., 2001]. In the search for enzymes involved in vitamin $\mathrm{C}$ production from glucose, two novel 2,5-di-keto-D-gluconic acid reductases were PCR amplified from the environment [Eschenfeldt et al., 2001]. These reductases displayed higher activity than other known reductases and they were more thermostable, making them ideal for application in biotechnology.

\section{Nitrilases, Nitrile Hydratases and Amidases}

Chemical hydrolysis of nitriles requires the presence of strong acids or bases at high temperatures and normally results in low yields. Therefore, there is much interest in using biocatalysts to carry out this reaction instead [Cantarella et al., 2006].

Nitriles can be hydrolyzed directly to carboxylic acid and ammonium by nitrilases or they are first converted to amides by nitrile hydratases and then the amide is converted to the corresponding carboxylic acid and ammonium by amidases [Liebeton and Eck, 2004].

Nitrile hydratases are used for the production of acrylamide and the vitamin nicotinamide [Brady D. et al., 2004]. In one metagenomic study, involving the screening of $3 \mathrm{~Gb} \mathrm{DNA}, 12$ novel nitrile dehydratases were detected [Liebeton and Eck, 2004].

In a general screening of a soil metagenomic library for biocatalysts, one amidase-positive clone was detected [Voget et al., 2003]. Amidases are used in the biosynthesis of $\beta$-lactam antibiotics, and in a study targeting amidases of the soil metagenome using enrichment, 7 amidasepositive clones were detected, one of which encoded a novel penicillin acylase [Gabor et al., 2004b, 2005].

Nitrilases are quite rare in bacterial genomes and less than 20 were reported prior to the application of metagenomics for their detection in environmental DNA [DeSantis et al., 2002; Podar et al., 2005; Robertson et al., 2004]. Two studies targeting environmental genomes report the detection of more than 337 novel nitrilases [De-
Santis et al., 2002; Robertson et al., 2004]. This has dramatically increased the amount of information about nitrilases, and the newly discovered diversity can be applied for the enantioselective production of hydroxy carboxylic acid derivatives [DeSantis et al., 2002; Podar et al., 2005].

\section{Oxidoreductases/Dehydrogenases}

A metagenomic study searching for the diversity of microorganisms in the environment capable of utilizing 4-hydroxybutyrate found 5 clones displaying novel 4hydroxybutyrate dehydrogenase activity [Henne et al., 1999]. In a recent metagenomic study the genes involved in metabolism of poly-3-hydroxybutyrate, a compound being considered as a substitute for fossil fuel-derived polymers, were screened for in environmental libraries [Wang et al., 2006a]. They found novel short-chain dehydrogenases/reductases which had $<35 \%$ similarity to known enzymes and thus could not have been detected using hybridization-based techniques such as PCR [Wang et al., 2006a].

Alcohol oxidoreductases capable of oxidizing shortchain polyols are useful biocatalysts in industrial production of chiral hydroxy esters, hydroxy acids, amino acids and alcohols [Knietsch et al., 2003b, c]. In a metagenomic study without enrichment, a total of 24 positive clones were obtained and tested for their substrate specificity [Knietsch et al., 2003c]. To improve the detection frequency, an enrichment was performed using glycerol or 1,2-propanediol, and in this study a further 24 positive clones were detected [Knietsch et al., 2003b]. The difference between the two studies was that without enrichment 300,000 clones per library per substrate were screened whereas with enrichment 100,000 clones per library were screened to obtain the same number of positive clones.

\section{Production of Bulk Chemicals}

In industrial processes 1,3-propanediol is used for the production of polyester fibers, polyurethanes and cyclic compounds [Knietsch et al., 2003a]. 1,3-Propanediol can be produced from glucose with the limiting step catalyzed by glycerol dehydratase [Knietsch et al., 2003a]. The aim is to overcome this by utilizing natural biocatalysts with higher activities [Nakamura and Whited, 2003]. A metagenomic survey for glycerol hydratases from the environment resulted in 7 positive clones, one of which displayed a level of catalytic efficiency and stability making it ideal for application in the production of 1,3-propanediol from glucose [Knietsch et al., 2003a]. 


\section{Antibiotics and Pharmaceuticals}

Metagenomics has greatly enhanced the discovery of novel pharmaceutically important small molecules. There have been two studies reporting the successful screening of soil metagenomic libraries for indirubin, a microbial product used in the treatment of diseases including leukemia [Lim et al., 2005; MacNeil et al., 2001].

A range of genes encoding for novel antibiotics have been detected in metagenomic libraries [Brady and Clardy, 2004, 2005a, b; Brady S.F. et al., 2004; Gillespie et al., 2002]. Palmitoylputrescine was detected in metagenomic DNA from a Bromeliad tank [Brady and Clardy, 2004] and an isocyanide-containing antibiotic was found in a soil metagenomic library [Brady and Clardy, 2005a]. Screening of seven different soil metagenomic libraries revealed 11 clones producing long-chain $\mathrm{N}$-acyltyrosine antibiotics and analysis of their synthases indicated that 10 of them were novel [Brady S.F. et al., 2004]. In a related study, other antibacterially active long-chain $\mathrm{N}$-acyl amino acids and their synthases were detected in a soil metagenome library [Brady and Clardy, 2005b]. Turbomycin $\mathrm{A}$ and $\mathrm{B}$, broad-spectrum antibiotics active against Gram-positive and Gram-negative bacteria, were found in a soil metagenomic library [Gillespie et al., 2002]. In a screening of 1,020 clones, 18 were found to produce terragines [Wang et al., 2000]. Altogether, this indicates that there are many novel antibiotics in the environment and metagenomics makes it possible to detect and characterize them. All the metagenome-derived novel antibiotics detected to date have been found in libraries maintained in Escherichia coli hosts except the terragines which were in a streptomycete host [Wang et al., 2000].

As well as finding novel antibiotics in metagenomic studies, a lot of information has been gained about the diversity of natural antibiotic resistance mechanisms [Diaz-Torres et al., 2003; Riesenfeld et al., 2004].

One of the earliest metagenomic studies to target antitumor polyketides and their synthases screened a soil library using PCR and found 12 unique nucleotide sequences [Courtois et al., 2003]. In a second soil metagenomic study, 139 polyketide synthase clones were found in 60,000 screened [Ginolhac et al., 2004]. As a greater diversity of polyketide synthases are detected, the range of new compounds which can be produced increases. Since then, metagenomic polyketide studies have concentrated on detecting a vast number of polyketides from symbionts of beetles and from marine environments [Piel et al., 2004a, b, 2005; Schirmer et al., 2005]. Pederin-type polyketides are only found in symbionts [Piel et al., 2004b]. Metagenomic screening strategies for detection of novel natural products can be enhanced by information gained from analysis of isolates. For example, a recent PCR-based screening of cyanobacterial isolates for enzymes of the phosphopantetheinyl transferase superfamily, which are involved in the synthesis of polyketides, generated 140 sequences from which a functional classification was performed in order to find out more about natural product synthesis by cyanobacteria [Copp and Neilan, 2006]. This sort of information can be incorporated into future metagenomic screens for marine natural products.

\section{Proteases}

Proteases are hydrolytic enzymes with important application in industry, in particular in detergents and in the food industry [Gupta et al., 2002]. A screening of a soil library, containing $100 \mathrm{Mb}$ DNA, for proteolytic activity found no positive clones [Rondon et al., 2000]. A second metagenomic study in which 100,000 plasmid clones were screened for proteolytic activity found one positive clone, which was determined to be novel by sequencing analysis [Gupta et al., 2002].

To date (June 2007), there are more than 80 articles reporting on a wide variety of metagenome-derived novel biocatalysts. The earliest articles reported mainly the detection of novel biocatalysts and it is still the case in more recent articles that more biocatalysts are detected than are characterized. The majority of all metegenome studies reports on the isolation of hydrolases EC 3-. Given the growing number of enzymes identified, it is an intriguing challenge to now establish biotechnological processes with these enzymes. However, it might be a very optimistic view to expect that metagenome-derived biocatalysts perform in general better than those already implemented in biotechnology processes. To our knowledge, no metagenome-derived enzymes have yet replaced enzymes from known bacterial isolates in any biotechnological application. It is probably more reasonable to expect that only those metagenome enzymes that carry novel and unusual features will end up in large-scale processes. This means that these enzymes should match at least one of the following two criteria: firstly, these enzymes should allow access to novel substrates and thereby generate products of which the synthesis was not possible with the enzymes already available, and secondly the metagenome-derived biocatalysts should function under conditions for which no classical enzymes have yet been identified. Only if we can identify such enzymes will it be of an advantage to implement them in any biotechnological production processes. 


\section{Strategies for Enhancement of Novel Enzyme Discovery}

A range of novel enzyme detection strategies have been developed which target different stages in the process of metagenomic library construction and screening.

\section{Selection of Environment}

Metagenomic studies fall into three main categories in terms of their selection of environments. The first group select environments naturally enriched for the target biocatalyst such as the search for xylanases in insect gut [Brennan et al., 2004]. The second group select highly genomically diverse environments such as soil and either directly extract and clone the DNA or subject the community first to enrichment and then proceed with extraction and cloning. The third group target extreme environments and search for biocatalysts which are stable under the conditions experienced by the microorganisms in the environment [Ferrer et al., 2005a].

While extreme environments do yield enzymes that catalyze reactions under extreme conditions, the variation may be quite limited, such as alkalophilic enzymes which function only over a narrow alkaline $\mathrm{pH}$ range. Also, many microorganisms growing under acidic or alkaline conditions are able to maintain their intracellular $\mathrm{pH}$ around neutral, meaning that only the properties of extracellular enzymes would reflect environmental conditions. Highly genomically diverse environments which are naturally less extreme and more heterogeneous in terms of being subjected to greater fluctuations on temperature, $\mathrm{pH}$ or salinity may provide biocatalysts which show a greater level of stability and activity over a wider range of conditions [Elend et al., 2006; Voget et al., 2006].

One of the most significant developments is the application of metagenomics for the detection of pharmaceutically relevant products (antibiotics, anticancer drugs, etc.) from symbiotic marine environments [Piel et al., 2004b, 2005; Wang, 2006b]. Symbiotic bacteria produce many natural products which were previously inaccessible because of the cultivation restraints of these organisms. The application of metagenomics has overcome this obstacle. However, it has been discovered that bacteria can contain many different pathways for the synthesis of a single natural product and the main challenge now is to identify the correct genes among many homologues [Piel et al., 2005].

Recovery of Novel Biocatalysts from Metagenomes
It must be noted that choice of an environment enriched for activity of the target biocatalyst does not guarantee the high detection frequency of that biocatalyst. One study targeted the metagenome of the bovine rumen, an environment naturally enriched for amylases, and found one amylase-like clone per 14,000 screened, representing $77 \mathrm{Mb}$ DNA [Ferrer et al., 2005b]. This was much lower than the rate of detection of amylases from soil where one positive clone was found per $12.5 \mathrm{Mb} \mathrm{DNA}$ screened [Rondon et al., 2000]. This may be related to the cloning vector used in each case: phagemids were applied in the bovine rumen metagenome study and bacterial artificial chromosomes in the soil study. It has been demonstrated that enzyme activity in plaque-based screens is lower than that detected in whole cell-based screens [Cottrell et al., 1999].

\section{Cloning Strategy}

The metagenomic DNA is cloned into either large insert or small insert libraries. Large insert libraries can be generated in cosmids [Courtois et al., 2003; Entcheva et al., 2001] or bacterial artificial chromosomes (BAC) [Rondon et al., 2000] or fosmids [Kim et al., 2006; Rhee et al., 2005]. Small insert libraries are maintained in plasmid vectors including pBluescript SK+ [Henne et al., 1999], pUC19 [Ranjan et al., 2005], pZero-2 [Gabor et al., 2004b] and ZAP phagemid vector [Ferrer et al., 2005a]. In the case of pZero-2, a lethal gene is inactivated by the incorporation of environmental DNA which keeps the level of clones containing a self-ligated vector to a minimum [Gabor et al., 2004b]. Small insert libraries contain on average ten times more clones than large-insert libraries covering the same amount of environmental DNA. While the reduced clone number makes large insert libraries easier to screen, the larger insert size and lower copy number makes detection of weakly expressed foreign genes more difficult [Daniel, 2005].

\section{Sequencing Metagenomic DNA}

The amount of information available about environmental genomes has been greatly increased by expansive sequencing projects such as that carried out with DNA collected from the Sargasso Sea [Venter et al., 2004]. Sequence-based analysis of genomic data from marine environmental libraries has revealed an abundance of hydrolytic enzymes including 113 cellulases and 20 lipases [Cottrell et al., 2005; Rhee et al., 2005]. The most abundant cellulase-like gene in the Sargasso Sea metagenomic library is celM, but biochemical analysis of a CelM protein revealed that it had peptidase activity but no cellulase

J Mol Microbiol Biotechnol 2009;16:25-37 
activity [Cottrell et al., 2005]. While sequencing analysis provides a great deal of information, it cannot be used to confirm gene function.

A sequencing-based analysis of a drinking water biofilm resulted in the detection of 21 partial lipase genes [Schmeisser et al., 2003]. A functional-based screening of the same biofilm detected 6 active lipolytic clones [Elend et al., 2006]. The lower number of lipolytic clones detected may be related to limitations in heterologous gene expression.

One of the most common uses of sequence information in metagenomics is to determine whether biocatalysts obtained by functional screening are novel so that biocatalysts that have already been characterized can be excluded from further analysis [Ginolhac et al., 2004].

\section{PCR Detection of Novel Biocatalysts}

PCR amplification of novel biocatalyst genes from environmental DNA limits detection to those genes which are genetically similar to already characterized genes. For example, a study of chitinases obtained from a marine environment comparing those from isolated bacteria with those obtained by PCR amplification from the environment revealed that the dominant cellulases detected in both cases were from $\alpha$-proteobacteria [Cottrell et al., 2000]. As the primers were designed from chitinase sequences from cultured bacteria, this level of similarity between the two studies could be expected. Despite this limitation, this method has been successfully applied for the detection of novel biocatalysts including lipases, chitinases and amylases [Bell et al., 2002; Cottrell et al., 2000; Jiang et al., 2006; Tang et al., 2006]. Combining PCR detection of small conserved regions of biocatalysts with genome walking to obtain upstream and downstream sequences flanking the fragments makes it possible to obtain and characterize the entire gene [Jiang et al., 2006].

\section{Range of Functional Screening Methods}

Many of the functional screening methods depend on plating metagenomic clones onto indicator agar and observing activity through color change or the formation of a halo surrounding the colony. Often they are methods derived from classical microbiology where they were previously applied for the analysis of single species rather than for screening of thousands of clones.

In some cases, different laboratories use different screening methods for the detection of the same type of biocatalyst. For example, for the detection of lipolytic clones the range of indicators used include tributyrin, triolein, bactolipid and $\alpha$-naphtylacetate [Elend et al., 2006;
Ferrer et al., 2005a, b; Henne et al., 2000; Rondon et al., 2000].

The functional screening methods all differ in their detection level sensitivity. One metagenomic study targeting chitinases from marine environments compared two functional screening approaches: a plaque assay using an analogue of chitin and a microtiter plate assay with phagemids adsorbed to cells and incubated with the same analogue of chitin [Cottrell et al., 1999]. With the plaque assay, 2 positive clones were detected and with the microtiter plate assay, 432 fluorescing cells were detected. Further analysis of 14 of the wells revealed 13 chitinasepositive clones with a stable phenotype [Cottrell et al., 1999]. The whole cell, microtiter plate assay was much more sensitive than the plaque assay, possibly due to the higher enzyme activity in the unlysed cells.

On the whole, less sensitive functional screening methods detect fewer biocatalysts but they are more active than those detected by more sensitive screens. The optimal screening method required depends whether a wide diversity of functional biocatalysts are required or just the most active.

\section{Laboratory Enrichment Cultures}

Searching for novel enzymes in metagenomic libraries often involves screening thousands of clones to find only a few positives. To enhance the likelihood of finding positive clones it is possible to generate a laboratory enrichment culture from the environmental sample material. The aim is to achieve an enrichment of the population carrying the target trait, such as biotin synthesis, esterase or amidase activity, by feeding the appropriate substrates to the sample and incubating them prior to DNA isolation [Elend et al., 2006; Entcheva et al., 2001; Ferrer et al., 2005a; Gabor et al., 2004b]. The enrichment for the target trait is balanced against overall loss of population diversity through cultivation. Both factors lead to an increase in the chance of finding positive clones. One important consideration is that the conditions used for the enrichment, such as temperature and $\mathrm{pH}$ range, may be reflected in the temperature and $\mathrm{pH}$ optima of the enzymes obtained. When no enrichment step is used then the characteristics of the obtained enzymes may be related to the conditions in their original environment. Enrichment can lead to a 3-fold increase in the detection frequency of positive clones [Knietsch et al., 2003a, b].

In a refinement of the enrichment method which incorporates developments from microbial ecology research, stable isotope labeling and fractionation of the DNA was used to target DNA from the population ac- 
tively metabolizing the labeled substrate and use it to generate the metagenomic library [Friedrich, 2006; Lueders et al., 2004; Schwarz et al., 2006]. In this way, gene detection frequencies were improved 3.8-fold in a metagenomic survey for coenzyme $B_{12}$-dependent glycerol dehydratases [Schwarz et al., 2006].

\section{Heterologous Gene Expression}

Functional screening strategies aim to detect the biocatalytic reaction first and then characterize the gene responsible. In this way, completely novel enzymes can be discovered. This approach requires that the metagenomic DNA be expressed in a heterologous host, usually $E$. coli. As can be expected with an expression-based system, it is limited when factors required for transcription and translation of the metagenomic DNA are not present in the host. A survey of 32 prokaryotic genomes found that only $40 \%$ of genes could be expressed using E. coli [Gabor et al., 2004a]. Also, even when a gene is expressed, the level of expression can be so low that it cannot be detected using functional screening. Recently, a transposon was developed which enables inducible expression over T7 promoters in both directions [Leggewie et al., 2006]. This transposon could be used to enhance gene expression and increase the likelihood of finding metagenomic enzymes through functional screening.

Improvements in heterologous expression systems for production of complex bacterial products, such as polyketides, help to optimize systems for functional screening in metagenomic research [Wenzel and Müller, 2005].

\section{Selection of Heterologous Host for Functional \\ Screening}

It is quite often reported in metagenomic studies that different positive clones are detected when different hosts are used [Li et al., 2005; Wang et al., 2006a]. For example, in a metagenomic screen for D-3-hydroxybutyrate dehydrogenase using both Sinorhizobium meliloti and E. coli $b d h A$ mutants, a host-specific detection was recorded as only one of 25 clones detected using S. meliloti was able to complement $E$. coli and none of the clones found using E. coli could be used to complement $S$. meliloti [Wang et al., 2006a].

In a metagenomic study where three different hosts were used to screen a metagenomic library, different positive clones were detected in each of the hosts used: E. coli, Pseudomonas putida and Streptomyces lividans [Martinez et al., 2004]. This clearly indicates that screening of metagenomic libraries can be improved when a range of

Recovery of Novel Biocatalysts from Metagenomes hosts are used. The heterologous hosts used in metagenomics are E. coli, P. putida, S. lividans, S. meliloti and Rhizobium leguminosarum [Li et al., 2005; Martinez et al., 2004; Wang et al., 2000; Wexler et al., 2005].

E. coli is used most often as a host for generating metagenomic libraries because it is genetically well defined and easy to transform. With the increase in genome-sequencing projects, many more microorganisms are now genetically defined and could be used as heterologous hosts. Of particular interest are microorganisms with alternative gene expression systems and a wider range of protein secretion mechanisms than E. coli as functional screening assays require secretion of the foreign protein.

\section{Substrate-Based Detection Systems}

In the SIGEX system the environmental DNA is cloned into a vector containing a $g f p$ reporter [Uchiyama et al., 2005]. Clones carrying the catabolic genes are activated in the presence of the target substrate. When the catabolite genes are expressed they in turn activate the $g f p$ reporter causing the cell to fluoresce. This, in combination with fluorescence activating cell sorting (FACS), greatly increases the number of recombinant clones that can be screened [Uchiyama et al., 2005]. There are some limitations to this method which include the fact that the catabolite genes have to be cloned in the same orientation as the reporter, transcriptional regulators have to be close to the catabolic genes, there are some catabolic genes which are not induced by the presence of the substrate and finally, the substrate must be transported to the cytoplasm. Despite this, SIGEX is a useful tool and can be developed for detection of genes involved in antibiotic synthesis or catabolism [Yun and Ryu, 2005].

\section{Product-Based Detection Systems}

A recent development in detection methods is the ability to detect intracellular biocatalytic activity by linking the product to a reporter gene [Mohn et al., 2006; van Sint Fiet et al., 2006]. One system is designed to detect benzoate and 2-hydroxybenzoate production from their respective aldehydes [van Sint Fiet et al., 2006]. Detection of the products is achieved by combining NahR, a transcriptional activator protein recognizing the products, with reporter and selection systems such as lacZ or tet $A$. This system was successfully applied with a detection frequency of 1 in 1 million. The above example can be applied for detection of nitrilases, amidases, aldehyde oxidases and aldehyde benzoates, indicating that detection is not limited to one enzyme but rather to the product 
which may be obtained by different biocatalytic reactions [van Sint Fiet et al., 2006].

Another example of product-related detection of biocatalysis is the development of genetic traps to detect biocatalytic activity [Mohn et al., 2006]. This system was developed for detection of the production of 1,2,4-trichlorobenzene (TCB) from $\gamma$-hexachlorocyclohexane $(\gamma-\mathrm{HCH})$ using a variant of the XylR transcriptional activator which responds to TCB and induces lacZ genes cloned downstream of a $P u$ promoter [Mohn et al., 2006]. They demonstrated that it was possible to modify the system using alternative promoters and reporter genes. Modifications to this system, such as application of alternative transcriptional regulators, could expand the range of biocatalysts detected [Konarzycka-Bessler and Jaeger, 2006].

\section{Continuing Search for Novel Biocatalysts}

The emphasis in metagenomic research remains more on improving the detection of novel biocatalysts rather than on improving the range of tests used for their biochemical characterization. Metagenomic studies need to broaden and improve the biochemical characterization of novel biocatalysts as well as improve screening and detection strategies. Also, to enable comparison between metagenomic biocatalysts requires the development and application of a range of standard tests, as it has been demonstrated that using different substrates to determine $\mathrm{pH}$ and temperature optima can result in a range of catalytic optima being detected [Tang et al., 2006]. Importantly, metagenomic research has to consider the final application of the biocatalysts and the current, specific requirements in biotechnology processes, such as the need for biocatalysts which are active and stable in ionic liquids. Finally, an interesting biocatalytic property can only be detected if the appropriate biochemical tests are developed and applied.

\section{Acknowledgements}

This work was supported by funds of the Competence Network Göttingen 'Genomikt' financed by the German Federal Ministry of Education and Research (BMBF).

\section{References}

Amann RI, Ludwig W, Schleifer KH: Phylogenetic identification and in-situ detection of individual microbial cells without cultivation. Microbiol Rev 1995;59:143-169.

Bell PJL, Sunna A, Gibbs MD, Curach NC, Nevalainen $\mathrm{H}$, Bergquist PL: Prospecting for novel lipase genes using PCR. Microbiology 2002;148:2283-2291.

-Brady D, Beeton A, Zeevaart J, Kgaje C, van Rantwijk F, Sheldon RA: Characterisation of nitrilase and nitrile hydratase biocatalytic systems. Appl Microbiol Biotechnol 2004;64: 76-85.

Brady SF, Chao CJ, Clardy J: Long chain $N$-acyltyrosine synthases from environmental DNA. Appl Environ Microbiol 2004;70: 6865-6870

Brady SF, Clardy J: Palmitoylputrescine, an antibiotic isolated from the heterologous expression of DNA extracted from Bromeliad tank water. J Nat Prod 2004;67:1283-1286.

Brady SF, Clardy J: Cloning and heterologous expression of isocyanide biosynthetic genes from environmental DNA. Angew Chem Int Ed 2005a;44:7063-7065.

Brady SF, Clardy J: N-Acyl derivatives of arginine and tryptophan isolated from environmental DNA expressed in Escherichia coli. Org Lett 2005b;7:3613-3616.
Brennan Y, Callen WN, Christoffersen L, Dupree $\mathrm{P}$, Goubet F, Healey S, Hernández M, Keller M, Li K, Palackal N, Sittenfeld A, Tamayo G, Wells S, Hazlewood GP, Mathur EJ, Short JM, Robertson DE, Steer BA: Unusual microbial xylanases from insect guts. Appl Environ Microbiol 2004;70:36093617.

Bronnenmeier K, Kern A, Liebl W, Staudenbauer WL: Purification of Thermotoga maritima enzymes for the degradation of cellulosic materials. Appl Environ Microbiol 1995;61: 1399-1407.

Cantarella M, Cantarella L, Gallifuoco A, Spera A: Use of a UF-membrane reactor for controlling selectively the nitrile hydratase-amidase system in Microbacterium imperiale CBS 498-74 resting cells. Case study: benzonitrile conversion. Enzyme Microb Technol 2006;38:126-134.

-Carstens M, Vivier MA, van Rensburg P, Pretorius IS: Overexpression, secretion and antifungal activity of the Saccharomyces cerevisiae chitinase. Ann Microbiol 2003;53:1528.

Chatterjee R, Yuan L: Directed evolution of metabolic pathways. Trends Biotechnol 2006;24: 28-38.

Collins T, Gerday C, Feller G: Xylanases, xylanase families and extremophilic xylanases. FEMS Microbiol Rev 2005;29:3-23.
Copp JN, Neilan BA: The phosphopantetheinyl transferase superfamily: phylogenetic analysis and functional implications in Cyanobacteria. Appl Environ Microbiol 2006;72: 2298-2305

Cottrell MT, Moore JA, Kirchman DL: Chitinases from uncultured marine microorganisms. Appl Environ Microbiol 1999;65:25532557.

Cottrell MT, Wood DN, Yu L, Kirchman DL: Selected chitinase genes in cultured and uncultured marine bacteria in the $\alpha$ - and $\gamma$-subclasses of the proteobacteria. Appl Environ Microbiol 2000;66:1195-1201.

Cottrell MT, Yu L, Kirchman DL: Sequence and expression analyses of Cytophaga-like hydrolases in a Western arctic metagenomic library and the Sargasso Sea. Appl Environ Microbiol 2005;71:8506-8513.

Courtois S, Cappellano CM, Ball M, Francou F$\mathrm{X}$, Normand P, Helynck G, Martinez A, Kolvek SJ, Hopke J, Osburne MS, August PR, Nalin R, Guérineau M, Jeannin P, Simonet $\mathrm{P}$, Pernodet J-L: Recombinant environmental libraries provide access to microbial diversity for drug discovery from natural products. Appl Environ Microbiol 2003;69:49-55.

Curtis TP, Sloan WT: Exploring microbial diversity - a vast below. Science 2005;309:13311333. 
Daniel R: The metagenomics of soil. Nat Rev Microbiol 2005;3:470-478.

-DeSantis G, Zhu Z, Greenberg WA, Wong K, Chaplin J, Hanson SR, Farwell B, Nicholson LW, Rand CL, Weiner DP, Robertson DE, Burk MJ: An enzyme library approach to biocatalysis: development of nitrilases for enantioselective production of carboxylic acid derivatives. J Am Chem Soc 2002;124: 9024-9025.

-Diaz-Torres ML, McNab R, Spratt DA, Villedieu A, Hunt N, Wilson M, Mullany P: Novel tetracycline resistance determinant from the oral metagenome. Antimicrob Agents Chemother 2003;47:1430-1432.

-Elend C, Leggewie C, Babiak P, Carballeira JD, Steele HL, Reymond J-L, Jaeger K-E, Streit WR: Isolation and biochemical characterization of two novel metagenome derived esterases. Appl Environ Microbiol 2006;72: 3637-3645.

-Elend C, Steele HL, Schmeisser C, Streit WR: Isolation and characterization of a metagenome-derived and cold-active lipase with high stereospecificity for (R)-ibuprofen esters. J Biotechnol 2007;130:370-377.

Entcheva P, Liebl W, Johann A, Hartsch T, Streit WR: Direct cloning from enrichment cultures, a reliable strategy for isolation of complete operons and genes from microbial consortia. Appl Environ Microbiol 2001;67: 89-99.

-Eschenfeldt WH, Stols L, Rosenbaum H, Khambatta ZS, Quaite-Randall E, Wu S, Kilgore DC, Trent JD, Donnelly MI: DNA from uncultured organisms as a source of 2,5-diketo-D-gluconic acid reductases. Appl Environ Microbiol 2001;67:4206-4214.

-Ferrer M, Beloqui A, Golyshina OV, Plou FJ, Neef A, Chernikova TN, Fernandez-Arrojo L, Ghazi I, Ballesteros A, Elborough K, Timmis KN, Golyshin PN: Biochemical and structural features of a novel cyclodextrinase from cow rumen metagenome. Biotechnol J 2007;2:207-213.

- Ferrer M, Golyshina OV, Chernikova TN, Khachane AN, Martins dos Santos VAP, Yakimov MM, Timmis KN, Golyshin PN: Microbial enzymes mined from the Urania deep-sea hypersaline anoxic basin. Chem Biol 2005a;12:895-904.

- Ferrer M, Golyshina OV, Chernikova TN, Khachane AN, Reyes-Duarte D, Martins dos Santos VAP, Strompl C, Elborough K, Jarvis G, Neef A, Yakimov MM, Timmis KN, Golyshin PN: Novel hydrolase diversity retrieved from a metagenome library of bovine rumen microflora. Environ Microbiol 2005b; 1996-2010.

Friedrich MW: Stable-isotope probing of DNA: insights into the function of uncultivated microorganisms from isotopically labelled metagenomes. Curr Opin Biotechnol 2006; 17:59-66.
Gabor EM, Alkema WBL, Janssen DB: Quantifying the accessibility of the metagenome by random expression cloning techniques. Environ Microbiol 2004a;6:879-886.

Gabor EM, de Vries EJ, Janssen DB: Construction, characterization, and use of small-insert gene banks of DNA isolated from soil and enrichment cultures for the recovery of novel amidases. Environ Microbiol 2004b;6: 948-958.

Gabor EM, de Vries EJ, Janssen DB: A novel penicillin acylase from the environmental gene pool with improved synthetic properties. Enzyme Microb Technol 2005;36:182-190.

Gans J, Wolinsky M, Dunbar J: Computational improvements reveal great bacterial diversity and high metal toxicity in soil. Science 2005;309:1387-1390.

Gillespie, DE, Brady SF, Bettermann AD, Cianciotto NP, Liles MR, Rondon MR, Clardy J, Goodman RM, Handelsman J: Isolation of antibiotics turbomycin $\mathrm{A}$ and $\mathrm{B}$ from a metagenomic library of soil microbial DNA. Appl Environ Microbiol 2002;68:43014306.

Ginolhac A, Jarrin C, Gillet B, Robe P, Pujic P, Tuphile K, Bertrand H, Vogel TM, Perrière G, Simonet P, Nalin R: Phylogenetic analysis of polyketide synthase I domains from soil metagenomic libraries allows selection of promising clones. Appl Environ Microbiol 2004;70:5522-5527.

-Grant S, Sorokin DY, Grant WD, Jones BE, Heaphy S: A phylogenetic analysis of Wadi el Natrun soda lake cellulase enrichment cultures and identification of cellulase genes from these cultures. Extremophiles 2004;8: 421-429.

- Gupta R, Beg QK, Lorenz P: Bacterial alkaline proteases: molecular approaches and industrial applications. Appl Microbiol Biotechnol 2002;59:15-22.

Handelsman J, Rondon MR, Brady SF, Clardy J, Goodman RM: Molecular biological access to the chemistry of unknown soil microbes: a new frontier for natural products. Chem Biol 1998;5:R245-249.

Healy FG, Ray RM, Aldrich HC, Wilkie AC, Ingram LO, Shanmugam KT: Direct isolation of functional genes encoding cellulases from the microbial consortia in a thermophilic, anaerobic digester maintained on ligocellulose. Appl Microbiol Biotechnol 1995;43: 667-674.

-Henne A, Daniel R, Schmitz RA, Gottschalk G: Construction of environmental DNA libraries in Escherichia coli and screening for the presence of genes conferring utilisation of 4hydroxybutyrate. Appl Environ Microbiol 1999;65:3901-3907.

Henne A, Schmitz RA, Bömeke M, Gottschalk G, Daniel R: Screening of environmental DNA libraries for the presence of genes conferring lipolytic activity on E. coli. Appl Environ Microbiol 2000;66:3113-3116.
Hoster F, Schmitz JE, Daniel R: Enrichment of chitinolytic microorganisms: isolation and characterisation of a chitinase exhibiting antifungal activity against phytopathogenic fungi from a novel Streptomyces strain. Appl Microbiol Biotechnol 2005;66:434442.

-Howard MB, EkborgNA, Weiner RM, Hutcheson SW: Detection and characterisation of chitinases and other chitin-modifying enzymes. J Ind Microbiol Biotechnol 2003;30: 627-635.

Hugenholtz P, Goebel BM, Pace NR: Impact of culture-independent studies on the emerging phylogenetic view of bacterial diversity. J Bacteriol 1998;180:4765-4774.

Jaeger K-E, Eggert T: Lipases for biotechnology. Curr Opin Biotechnol 2002;13:390-397.

-Jaeger K-E, Eggert T, Eipper A, Reetz MT: Directed evolution and the creation of enantioselective biocatalysts. Appl Microbiol Biotechnol 2001;55:519-530.

Jiang Z, Wang H, Ma Y, Wei D: Characterisation of two novel lipase genes isolated directly from environmental sample. Appl Microbiol Biotechnol 2006;70:327-332.

Kim J-N, Seo M-J, Cho E-A, Lee S-J, Kim S-B, Cheigh C-I, Pyun Y-R: Screening and characterisation of an esterase from a metagenomic library. J Microbiol Biotechnol 2005; 15:1067-1072.

Kim Y-J, Choi G-S, Kim S-B, Yoon G-S, Kim Y-S, Ryu Y-W: Screening and characterisation of a novel esterase from a metagenomic library. Protein Expr Purif 2006;45:315-323.

Knietsch A, Bowein S, Whited G, Gottschalk G, Daniel R: Identification and characterisation of coenzyme $\mathrm{B}_{12}$-dependent glycerol hydratase- and diol dehydratase-encoding genes from metagenomic DNA libraries derived from enrichment cultures. Appl Environ Microbiol 2003a;69:3048-3060.

Knietsch A, Waschkowitz T, Bowien S, Henne A, Daniel R: Construction and screening of metagenomic libraries derived from enrichment cultures: generation of a gene bank for genes conferring alcohol oxidoreductase activity on Escherichia coli. Appl Environ Microbiol 2003b;69:1408-1416.

Knietsch A, Waschkowitz T, Bowien S, Henne A, Daniel R: Metagenomes of complex microbial consortia derived from different soils as sources for novel genes conferring formation of carbonyls from short-chain polyols on Escherichia coli. J Mol Microbiol Biotechnol 2003c;5:46-56.

Konarzycka-Bessler M, Jaeger K-E: Select the best: novel biocatalysts for industrial applications. Trends Biotechnol 2006;24:248250.

Lämmle K, Zipper H, Breuer M, Hauer B, Buta C, Brunner H, Rupp S: Identification of novel enzymes with different hydrolytic activities by metagenome expression cloning. J Biotechnol 2007;127:575-592. 
Lee CC, Kibblewhite-Accinelli RE, Wagschal K, Martinez A, Kolvek SJ, Yip CLT, Hopke J, Brown Robertson GH, Wong DWS: Cloning and characterisation of a cold-active xylanase enzyme from an environmental library. Extremophiles 2006a;10:295-300.

Lee M-H, Lee C-H, Oh T-K, Song JK, Yoon J-H: Isolation and characterization of a novel lipase from a metagenomic library of tidal flat sediments: evidence for a new family of bacterial lipases. Appl Environ Microbiol 2006b;72:7406-7409.

Lee S-W, Won K, Lim HK, Kim J-C, Choi GJ, Cho KY: Screening for novel lipolytic enzymes from uncultured soil microorganisms. Appl Microbiol Biotechnol 2004;65: 720-726.

- Leggewie C, Henning H, Schmeisser C, Streit WR, Jaeger K-E: A novel transposon for functional screening of DNA libraries. J Biotechnol 2006; 123:281-287.

- Leresche JE, Meyer H-P: Chemocatalysis and biocatalysis (biotransformation): some thoughts of a chemist and of a biotechnologist. Org Process Res Dev 2006;10:572-580.

-Li Y, Wexler M, Richardson DJ, Bond PL, Johnston AWB: Screening a wide host-range, waste-water metagenomic library in tryptophan auxotrophs of Rhizobium leguminosarum and of Escherichia coli reveals different classes of cloned trp genes. Environ Microbiol 2005;7:1927-1936.

Liebeton K, Eck J: Identification and expression in E. coli of novel nitrile hydratases from the metagenome. Eng Life Sci 2004;4:557-562.

-Liebl W, Ruile P, Bronnenmeier K, Riedel K, Lottspeich F, Greif I: Analysis of a Thermotoga maritima DNA fragment encoding two similar thermostable cellulases, CelA and CelB, and characterisation of the recombinant enzymes. Microbiology 1996;142:2533-2542.

-Lim HK, Chung EJ, Kim J-C, Choi GJ, Jang KS, Chung YR, Cho KY, Lee S-W: Characterisation of a forest soil metagenome clone that confers indirubin and indigo production on Escherichia coli. Appl Environ Microbiol 2005;71:7768-7777.

Lorenz P, Eck J: Metagenomics and industrial applications. Nat Rev Microbiol 2005;3:510516.

- Lueders T, Manefield M, Friedrich MW: Enhanced sensitivity of DNA- and RNA-based stable isotope probing by fractionation and quantitative analysis of isopycnic centrifugation gradients. Environ Microbiol 2004;6: 73-78.

Lynd LR, Weimer PJ, van Zyl WH, Pretorius IS: Microbial cellulose utilisation: fundamentals and biotechnology. Microbiol Mol Biol Rev 2002;66:506-577.

-MacNeil IA, Tiong CL, Minor C, August PR, Grossman TH, Loiacono KA, Lynch BA, Phillips T, Narula S, Sundaramoorthi R, Tyler A, Aldredge T, Long H, Gilman M, Holt D, Osburne MS: Expression and isolation of antimicrobial small molecules from soil DNA libraries. J Mol Microbiol Biotechnol 2001;3:301-308. KA, MacNeil IA, Osburne MS: Genetically modified bacterial strains and novel bacterial artificial chromosome shuttle vectors for constructing environmental libraries and detecting heterologous natural products in multiple expression hosts. Appl Environ Microbiol 2004;70:2452-2463.

Michel G, Nyval-Collen P, Barbeyron T, Czjzek M, Helbert W: Bioconversion of red seaweed galactans: a focus on bacterial agarases and carrageenases. Appl Microbiol Biotechnol 2006;71:23-33.

Mohn WW, Garmendia J, Galvao TC, de Lorenzo V: Surveying biotransformations with à la carte genetic traps: translating dehydrochlorination of lindane $(\gamma$-hexachlorocyclohexane) into lacZ-based phenotypes. Environ Microbiol 2006;8:546-555.

- Nakamura CE, Whited GM: Metabolic engineering for the microbial production of 1,3propanediol. Curr Opin Biotechnol 2003;14: 454-459.

-Ouverney CC, Fuhrman JA: Marine planktonic Archaea take up amino acids. Appl Environ Microbiol 2000;66:4829-4833.

Pakchung AAH, Simpson PJL, Codd R: Life on Earth. Extremophiles continue to move the goal posts. Environ Chem 2006;3:77-93.

- Piel J, Butzke D, Fusetani N, Hui D, Platzer M, Wen G, Matsunaga S: Exploring the chemistry of uncultivated bacterial symbionts: antitumour polyketides of the pederin family. J Nat Prod 2005;68:472-479.

Piel J, Hui D, Fusetani N, Matsunaga S: Targetting modular polyketide synthases with iteratively acting acyltransferases from metagenomes of uncultured bacterial consortia. Environ Microbiol 2004a;6:921-927.

Piel J, Hui D, Wen G, Butzke D, Platzer M, Fusetani N, Matsunaga S: Antitumour polyketide biosynthesis by an uncultivated bacterial symbiont of the marine sponge Theonella swinhoei. Proc Natl Acad Sci USA 2004b;101: 16222-16227.

- Podar M, Eads JR, Richardson TH: Evolution of a microbial nitrilase gene family: a comparative and environmental genomics study. BMC Evol Biol 2005;5:42.

Purcarea C, Herve G, Cunin R, Evans DR: Cloning, expression, and structure analysis of carbamate kinase-like carbamoyl phosphate synthetase from Pyrococcus abyssi. Extremophiles 2001;5:229-239.

- Ragauskas AJ, Williams CK, Davidson BH, Britovsek G, Cairney J, Eckert CA, Frederick WJ Jr, Hallett JP, Leak DJ, Liotta CL, Mielenz JR, Murphy R, Templer R, Tschaplinski T: The path forward for biofuels and biomaterials. Science 2006;311:484-489.

Ranjan R, Grover A, Kapardar RK, Sharma R: Isolation of novel lipolytic genes from uncultured bacteria of pond water. Biochem Biophys Res Commun 2005;335:57-65.
- Rees HC, Grant S, Jones B, Grant WD, Heaphy S Detecting cellulase and esterase enzyme activities encoded by novel genes present in environmental DNA libraries. Extremophiles 2003;7:415-421.

Rhee J-K, Ahn D-G, Kim Y-G, Oh J-W: New thermophilic and thermostable esterase with sequence similarity to the hormone-sensitive lipase family, cloned from a metagenomic library. Appl Environ Microbiol 2005;71: 817-825.

-Richardon TH, Tan X, Frey G, Callen W, Cabell M, Lam D, Macomber J, Short JM, Robertson DE, Miller C: A novel, high-performance enzyme for starch liquefaction. J Biol Chem 2002;277:26501-26507.

- Riesenfeld CS, Goodman RM, Handelsman J: Uncultured soil bacteria are a reservoir of new antibiotic resistance genes. Environ $\mathrm{Mi}$ crobiol 2004;6:981-989.

Robertson DE, Chaplin JA, DeSantis G, Podar M, Madden M, Chi E, Richardson T, Milan A, Miller M, Weiner DP, Wong K, McQuaid J, Farwell B, Preston LA, Tan X, Snead MA, Keller M, Mathur E, Kretz PL, Burk MJ, Short JM: Exploring nitrilase sequence space for enantioselective catalysis. Appl Environ Microbiol 2004;70:2429-2436.

Rondon MR, August PR, Bettermann AD, Brady SF, Grossman TH, Liles MR, Loiacono KA, Lynch BA, MacNeil IA, Minor C, Tiong CL, Gilman M, Osburne MS, Clardy J, Handelsman J, Goodman RM: Cloning the soil metagenome: a strategy for accessing the genetic and functional diversity of uncultured microorganisms. Appl Environ Microbiol 2000;66:2541-2547.

Rothschild LJ, Mancinelli RL: Life in extreme environments. Nature 2001;409:1092-1101.

Schirmer A, Gadkari R, Reeves CD, Ibrahim F, DeLong EF, Hutchinson CR: Metagenomic analysis reveals diverse polyketide synthase gene clusters in microorganisms associated with the marine sponge Discodermia dissoluta. Appl Environ Microbiol 2005;71: 4840-4849.

Schmeisser C, Stöckigt C, Raasch C, Wingender J, Timmis KN, Wenderoth DF, Flemming HC, Liesegang H, Schmitz RA, Jaeger K-E, Streit WR: Metagenome survey of biofilms in drinking-water networks. Appl Environ Microbiol 2003;69:7298-7309.

-Schmidt TM, DeLong EF, Pace NR: Analysis of a marine picoplankton community by $16 \mathrm{~S}$ rRNA gene cloning and sequencing. J Bacteriol 1991;173:4371-4378.

-Schwarz S, Waschkowitz T, Daniel R: Enhancement of gene detection frequencies by combining DNA-based stable-isotope probing with the construction of metagenomic DNA libraries. World J Microbiol Biotechnol 2006; 22:363-367.

Steele HL, Streit WR: Metagenomics: advances in ecology and biotechnology. FEMS Microbiol Lett 2005;247:105-111. 
-Streit WR, Daniel R, Jaeger K-E: Prospecting for biocatalysts and drugs in the genomes of non-cultured microorganisms. Curr Opin Biotechnol 2004;15:285-290.

- Streit WR, Schmitz RA: Metagenomics: the key to uncultured microbes. Curr Opin Microbiol 2004;7:492-498.

- Tang K, Utairungsee T, Kanokratana P, Sripang $\mathrm{R}$, Champreda V, Eurwilaichitr L, Tanapongpipat S: Characterisation of a novel cyclomaltodextrinase expressed from environmental DNA isolated from Bor Khleung hot spring in Thailand. FEMS Microbiol Lett 2006;260:91-99

- Tsai YL, Olson BH: Rapid method for separation of bacterial DNA from humic substances in sediments for polymerase chain reaction. Appl Environ Microbiol 1992;58:22922295.

- Uchiyama T, Abe T, Ikemura T, Watanabe K: Substrate induced gene expression screening of environmental metagenome libraries for isolation of catabolic genes. Nat Biotechnol 2005;23:88-93.
Van Sint Fiet S, van Beilen JB, Witholt B: Selection of biocatalysts for chemical synthesis. Proc Natl Acad Sci USA 2006;103:16931698. $>$ enter JC, Remington K, Heidelberg JF, Halpern AL, Rusch D, Eisen JA, Wu D, Paulsen I, Nelson KA, Nelson W, Fouts DE, Levy S, Knap AH, Lomas MW, Nealson K, White O, Peterson J, Hoffman J, Parsons R, Baden-Tillson H, Pfannkoch C, Rogers Y-H, Smith HO: Environmental genome shotgun sequencing of the Sargasso Sea. Science 2004;304:66-74.

Voget S, Leggewie C, Uesbeck A, Raasch C, Jaeger K-E, Streit WR: Prospecting for novel biocatalysts in a soil metagenome. Appl Environ Microbiol 2003;69:6235-6242.

Voget S, Steele HL, Streit, WR: Characterisation of a metagenome-derived halotolerant cellulase. J Biotechnol 2006;126:26-36.

Wang C, Meek DJ, Panchal P, Boruvka N, Archibald FS, Driscoll BT, Charles TC: Isolation of poly-4-hydroxybutyrate metabolism genes from complex microbial communities by phenotypic complementation of bacterial mutants. Appl Environ Microbiol 2006a;72: 384-391.
Wang G: Diversity and biotechnological potential of the sponge-associated microbial consortia. J Ind Microbiol Biotechnol 2006b;33: 545-551.

Wang G-Y-S, Graziani E, Waters B, Pan W, Li X, McDermott J, Meurer G, Saxena G, Andersen RJ, Davies J: Novel natural products from soil DNA libraries in a streptomycete host. Org Lett 2000;2:2401-2404.

Wenzel SC, Müller R: Recent developments towards the heterologous expression of complex bacterial natural product biosynthetic pathways. Curr Opin Biotechnol 2005;16: 594-606.

Yoon, S, Kim S, Ryu Y, Kim TD: Identification and characterization of a novel (S)-ketoprofen-specific esterase. Int J Biol Macromol 2007; 41:1-7.

-Yun J, Kang S, Park S, Yoon H, Kim M-J, Heu S, Ryu S: Characterization of a novel amylolytic enzyme encoded by a gene from a soil-derived metagenomic library. Appl Environ Microbiol 2004;70:7229-7235.

-Yun J, Ryu S: Screening for novel enzymes from metagenome and SIGEX, as a way to improve it. Microb Cell Fact 2005;4:8. 